\title{
Learning motivation and student achievement: description analysis and relationships both
}

\author{
Ari Riswanto $\left.{ }^{*}\right) 1$, Sri Aryani ${ }^{2}$ \\ 1,2 STKIP PGRI Sukabumi - West Java - Indonesian \\ *) Corresponding author, $\equiv$ e-mail: aririswanto@stkippgrisukabumi.ac.id
}

\begin{abstract}
Education is very important for humans, through the education throughout the world will increasingly flourish. However, if faced with the activities within the learning process, not a few men (students) who have less motivation in learning activities. This resulted in fewer maximal learning processes and in turn will affect student achievement. This study focuses to discuss matters relating to the motivation to learn and student achievement, with the aim of strengthening the importance of motivation in the learning process so that a clear relationship with student achievement. The method used is descriptive analysis and simple correlation to the 97 students taking the course introduction to Microeconomics and Indonesian. The conclusion from this research is the students have a good record if it has a well and motivated as well, and this study concludes their tie's difference between learning motivation and achievement of students on two different courses.
\end{abstract}

Keywords: Learning Motivation, Student Achievement, Descriptive and Simple Correlation Analysis.

How to Cite: Ari Riswanto., Sri Aryani. (2017). learning motivation and student achievement : descriptive analysis and relationships both. Couns-Edu: International Journal of Counseling and Education, 2(1): pp. 42-47. DOI: $10.23916 / 002017026010$

\section{Introduction}

Increased development within a country is an indicator of development and progress within the field of science and education (Bamiro, 2015). This indicates an important role for the development of science and technology to the development within a country. The country currently needs to be tuberous on achievements produced by the process of learning activities at academic institutions, because they some countries have a fear that the process of learning, and the demands of school will end with achievement results unsatisfactory (McInerney, Cheng, Mok, \& Lam, 2012; Nemeth \& Long, 2012), Accordingly, student achievement in formal academic institutions can be observed from the rank-actualization in students' learning activities (Joy, Hamilton, \& Ekeke, 2013; Levpuscek \& Zupancic, 2008). Indicators of learning achievement can be seen on the standard value set by each institution and on changes in the level of achievement of each student from year to year in all academic subjects in tests and assessments (Firmender, Gavin, \& McCoach, 2014; Lee, Liu, Amo, \& Wang, 2013; Shatzer, Caldarella, Hallam, \& Brown, 2013; Swanson, Valiente, Lemery-Chalfant, \& Caitlin O’Brien, 2011). 
Additionally, student achievement can describe the level of achievement of students in terms of knowledge, skills and experience of learning formulated by learning objectives for the school curriculum (Levpuscek \& Zupancic, 2008; Nemeth \& Long, 2012). The test results were followed by students reflects the extent to which students can achieve learning goals in each subject in educational institutions, thus increasing student achievement illustrates the quality of education is getting better. Likewise, declining student achievement illustrates the quality of education is low (Joy et al., 2013; Lee et al., 2013; Levpuscek \& Zupancic, 2008; Shatzer et al., 2013).

Theory that will be used in this research is the theory of learning outcomes expressed by Gagne. Gauge states that learning is a set of cognitive processes that change the nature of environmental stimulation, passing information processing and become the new capabilities. Gauge theory shows that learning is influenced by three main components, namely external conditions, internal and learning outcomes (Mudjiono, 2009). While the factors that affect student achievement according to previous studies including students 'motivation (Levpuscek \& Zupancic, 2008), students' perception of the school environment (Gietz \& McIntosh, 2014), the quality of teachers (Darling-Hammond, 2000; Heck, 2007; Jennings \& Greenberg, 2009; Joy et al., 2013; Kunter et al., 2013; Lee et al., 2013; Muzenda, 2013; Ottmar, Rimm-Kaufman, Larsen, \& Berry, 2015; Wayne \& Youngs, 2003), the attitude of teachers (Levpuscek \& Zupancic, 2008), learning model used by the teacher; a simulation model for economic subjects, blended learning, discovery and think pair share (A1-Ani, 2013; Bamiro, 2015; Porter, Riley, \& Ruffer, 2004), learning strategies applied by the teacher; Instructional (Firmender et al., 2014), the class composition (Gottfried, 2012), the type of leadership of school leaders (Shatzer et al., 2013), motherly support (Swanson et al., 2011), motherly controls (Levpuscek \& Zupancic, 2008; Swanson et al., 2011) and state standards that regulate education (Lee et al., 2013).

This study examines the relationships between the motivational factors of student learning and academic achievement gained by the student. Contribution of student achievement is supported by the motivation of students in schools (Heck, 2007; Lee et al., 2013; Levpuscek \& Zupancic, 2008; Ottmar et al., 2015). Students' motivation to use the theory of convergence of the development within the individual is determined by factors originating from within and factors that come from outside oneself. Motivation is an internal process that is one of the main factors that determines the success rate of student learning (Levpuscek \& Zupancic, 2008). Motivation is important in determining how many students will be learning from a learning activity or how much to absorb the information presented to them. Students are motivated to learn something will use higher cognitive processes in learning the material, so that students will absorb the material better. These motivation levels are determined by the level of meaningfulness of teaching materials and learning activities, which are owned by the students concerned (Djamarah, 2008).

\section{Method}

This research was done in less than one year, then the method used is a crosses sectional method, the method of research by improving the objects within a certain time or not sustainable in the long term (Husein, 2011). In this, research uses exemplifying research type and statistics with simple correlation analysis. By using exemplifying type obtained an overview of the motivation to learn and student achievement. While statistical analyzes were performed to determine the extent on the relationship between the variables of learning motivation and student achievement. In this study using other than using First Data, obtained from the first hand to be analyzed next to find a solution or the problem studied (Uma, 2006). Sources of First Data in this study are all data obtained from interviews, observations, and questionnaires taken from PGRI STKIP Sukabumi students who follow the course is an introduction to Microeconomics and Indonesian Course. As for the incidental data collected by the researchers, the data published as the journal and other statistics, and information available from the publication or nonpublication either inside or outside the organization, all of which can be useful for researchers (Uma, 2006). This study uses a value documentation Final Exam results as incidental data. Generalization region consisting of objects or subjects that have certain qualities and characteristics defined by the 


\section{COUNS-EDU •}

Vol.2, No.1, March 2017

researchers to learn and then drawn conclusions called Population (Sugiyono, 2015). In this study, the population is students STKIP PGRI Sukabumi and become Sample's researches were all students who follow the course is an introduction to Microeconomics and Indonesian Course Academic Year 2016-2017 amounted to 97 students. Descriptive statistics were used to help describe the circumstances (facts) which are actually from a study. This analysis relates to methods of collecting and presenting data to provide useful information. Illustrative statistics only provide information in the data held and did not draw any conclusions. With illustrative statistics, the data set obtained will be presented with a quick, neat, and may provide the core of the existing data set. Descriptive data analysis conducted to describe the condition of each study variable, namely: how the motivation to learn (X) and how student achievement (Y). Hypothesis testing using statistical analysis with analysis tools using a simple correlation analysis. Correlation analysis is used to determine the amount of learning achievement relationship's dependent variable $(\mathrm{Y})$ and student learning motivation $(\mathrm{X})$. Before the test simple correlation analysis, first tested the requirements analysis, including: normality test, homogeneity test, linearity test and multicollinearity test.

\section{Results and Discussions}

\section{Learning Motivation}

The results of research related to learning motivation of students in universities, in the course introduction to Economics in distribution can be explained that out of 97 students who studied $9.28 \%$ have fewer categories; $34.02 \%$ had a mild category; 31.96 have an superior category, and $27.74 \%$ have a very superior category. While on the subject of motivation to learn Indonesian students in distribution can be explained that out of 97 students who studied $8.25 \%$ have fewer categories; $43.30 \%$ had a mild category; 29.90 have an superior category, and $18.56 \%$ have a very superior category.

Theoretically that motivation to learn it is something that drives it, move it, and engage students in learning (Endang Sri Astuti, 2010). Motivation can be defined as a process whereby goal-directed activity was investigated and sustained consisting of inherent motivation (the motivation that comes from within a person) and extrinsic motivation (motivation that arises because of the encouragement from the outside). Inherent motivation is a motivation that comes from within the individual itself. While extrinsic motivation is a motivation that emerged from outside the individual and often involves the appreciation of others. (Omar, Jain, \& Noordin, 2013). Likewise, when a person's behavior is triggered internally by someone for his own benefit or curiosity emerged of itself is called intrinsic motivation. In contrast, extrinsic motivation is when an individual is affected action of external factors that exist outside it, such as awards, punishment, or social pressures (Arens, Morin, \& Watermann, 2015).

If you look at the results by the associated descriptive motivation showed that $52.58 \%$ of all survey respondents, in this case the student has good and very good notices Danal either follow the lecture course introduction to Microeconomics or Indonesian. Motivation is growing due to the course using the method of innovation, creative and fun, in addition to the capacity and capability of lecturers manage and deliver lectures to be decisive for the success of learning, especially when the motivation to learn student's womanly main focus. this is in line with research conducted by Levpušc oak, Melita Puklek and Zupanc ice, Maja, which revealed the results of his research that the students' motivation for achievement is influenced by parental involvement in educational activities and behavior of teachers who are in the classroom (Levpuscek \& Zupancic, 2008). Moreover, that motivation has a very important effect upon the attitudes and behavior of student learning and motivation that focus on academic determine student achievement (Linnenbrink, E.A., Pintrich, 2002).

\section{Student Achievement}

The results showed in the distribution of student achievement conditions were taken from the results of student test scores obtained as follows: of the 97 students who conducted the research as respondents 
showed that $9.28 \%$ had fewer categories; $27.84 \%$ had a mild category; 35.05 have an superior category, and $27.84 \%$ have a very superior category. Meanwhile, the results of research into the subject show the distribution of Indonesian student achievement results as follows: of the 97 students who conducted the research as respondents showed that $10.31 \%$ had fewer categories; $34.02 \%$ had a mild category; 35.05 have an superior category, and $20.62 \%$ have a very superior category.

It theoretically is meant by achievement or often called learning outcomes is the capability of a person caused by the stimulus coming from the external environment and cognitive processes performed by the students. Gauge in this case believes that learning is influenced by factors in students and factors outside the student itself where the two interact. Besides learning consists of three main component's namely surface conditions that stimulus from the environment where he is in the process of learning, the interior condition that describes the interior state of the students themselves and the conscious process of students, as well as learning outcomes that describe verbal information possessed by students, intellectual skills, motoric skills, attitudes and conscious finesse students. Internal conditions will interact with the surface conditions during the process of learning and of the interaction, it will behold the learning outcomes (Syaiful, 2012).

Furthermore, in terms of student achievement on the course introduction to Microeconomics and Indonesian subjects showed that $59.28 \%$ of the students have an superior record and very superior. Student achievement is right now will not be separated from the current conditions among the students followed the lecture, whether positively motivated or otherwise, or the students were very enthusiastic in following all the lectures that have been agreed upon. This is similar to research conducted by Wayne, A. J \& Youngs, $\mathrm{P}$, which describes the results of research that in the case of universities and teacher assessment tests scores, there is a beneficial correlation in improving student achievement (Wayne \& Youngs, 2003). Furthermore, that there is beneficial and significant correlation between learning creativity, use of instructional media power point, both directly and indirectly to the learning outcomes (Tirtarahardja, $U$ dan La Sulo, 2012).

\section{Relations Learning Motivation and Student Achievement}

The results of the statistical calculation show that there are differences in the correlation coefficient between the relationship of motivation to learn in an introductory course micro- economic relations of the subject of motivation to learn Indonesian. In the course introduction to Microeconomics has a positive relationship between learning motivation and direction for the achievement of students with a correlation coefficient of $r=0.81$ and entered into the criteria of very high and almost perfect, which means that $81 \%$ of student's achievement STKIP PGRI Sukabumi influenced by the students' learning motivation and 19\% influenced by other factors, this is due to the method of innovation, creative and fun while students attend the lecture, the lecturer method, collaborative learning and cooperative, besides references used based technology and the results from previous research by involving students as subject's reviewer lecture material, This is true of course Indonesian, although the correlation coefficient between learning motivation and achievement of students with a value of $r=0.79$ and entrance into the category of high, it is because the lecturers in these case educators have high psychological ability in the teaching process and education so that the capacity of the faculty pedagogical lectures to manage activities optimally and quality.

If you see the results from the correlation calculation above, it can be said that the motivation to learn is good to have a beneficial relationship to student achievement, especially students who are in the environment STKIP PGRI Sukabumi. The study reinforces previous studies that revealed that there is an significant relationship between learning motivation on student achievement (Daniko, 2012; Siska Eko Mawarsih, 2013) and There is an significant beneficial effect between family environment, school environment, learning discipline as well as the motivation to study the learning achievement (Aminah, 2014). 


\section{Conclusions}

This study described of learning motivation students, student achievement, and also the relationship between the two. This study concluded that the learning motivation of students on two subjects that used as a reference, the course's introduction to Microeconomics and subjects Indonesian, in the course introduction to Microeconomics majority of student's mask into class have excellent motivation and excellent, as are the subjects Indonesian, motivation students classified as well and radically excellent, although there is a difference in value and an radically small number to the variable motivation to learn. Further to student achievement, from research conducted at the respondents, it was found that the value of learning achievement in the two subjects has a tendency stretcher good, and quite a few are classified as very well. Therefore, it is important the students get the facility in order to generate motivation to learn to be better. From the research, showed that the simple correlation test results showed that the motivation to learn in the course introduction to Microeconomics has a relationship with a higher than with the calculated correlation test on subjects Indonesian. This is in addition because the motivation is built and developed in the lecture, the competence of lecturers, student interest; learning environments also have a close relationship in maximizing student achievement.

\section{Acknowledgments}

This paper was written with financial support from a research grant from Campus STKIP PGRI Sukabumi - West Java - Indonesia, Allocated through Institute for Research and Community Service (LPPM), Faculty of Social Sciences Education STKIP PGRI Sukabumi to Economic Education Studies Program, Grant Project No. 009/2016

\section{References}

Al-Ani, W. T. (2013). Blended Learning Approach Using Moodle and Student's Achievement at Sultan Qaboos University in Oman. Journal of Education \& Learning, 2(3), 96-110. http://doi.org/10.5539/jel.v2n3p96

Aminah, I. S. S. ; Y. S. (2014). Pengaruh Lingkungan Keluarga, Lingkungan Sekolah, Disiplin Belajar dan Motivasi Belajar terhadap Prestasi Belajar Ekonomi Siswa SMA Kelas XI IPS SMA PGRI 1 Taman Pemalang. Economic Education Analysis Journal, 3(1), 46-51.

Arens, a. K., Morin, A. J. S., \& Watermann, R. (2015). Relations between classroom disciplinary problems and student motivation: Achievement as a potential mediator? Learning and Instruction, 39, 184-193. http://doi.org/10.1016/j.learninstruc.2015.07.001

Bamiro, A. O. (2015). Effects of Guided Discovery and Think-Pair-Share Strategies on Secondary School Students' Achievement in Chemistry. SAGE Open, 5(1), 1-7. http://doi.org/10.1177/2158244014564754

Daniko, P. (2012). Hubungan Antara Pemahaman Materi, Motivasi Belajar, Dan Prestasi Belajar Pada Siswa Kelas VIII SMP Taman Dewasa Ibu Pawiyatan Yogyakarta Tahun 2012. Universitas Ahmad Dahlan Yogyakarta.

Darling-Hammond, L. (2000). Teacher Quality and Student Achievement : A Review of State Policy Evidence Previous Research. Education, 8(1), 1-44. http://doi.org/10.1038/sj.clp

Djamarah, S. B. (2008). Psikologi Belajar (Kedua). Jakarta: Rineka Cipta.

Endang Sri Astuti, R. (2010). Bahan Dasar Untuk Pelayanan Konseling Pada Satuan Pendidikan Menengah (1st ed.). Jakarta: grasindo.

Firmender, J. M., Gavin, M. K., \& McCoach, D. B. (2014). Examining the Relationship Between Teachers' Instructional Practices and Students' Mathematics Achievement. Journal of Advanced Academics, 25(3), 214-236. http://doi.org/10.1177/1932202X14538032

Gietz, C., \& McIntosh, K. (2014). Relations Between Student Perceptions of Their School Environment and Academic Achievement. Canadian Journal of School Psychology, 29 (3 ), 161-176. http://doi.org/10.1177/0829573514540415

Gottfried, M. (2012). Peer Effects in Urban Schools: Assessing the Impact of Classroom Composition on Student Achievement. Educational Policy, 28(5), 607-647. http://doi.org/10.1177/0895904812467082 
Heck, R. H. (2007). Examining the Relationship Between Teacher Quality as an Organizational Property of Schools and Students' Achievement and Growth Rates. Educational Administration Quarterly, 43(4), 399-432. http://doi.org/10.1177/0013161X07306452

Husein, U. (2011). Metode Penelitian Untuk Skripsi dan Tesis Bisnis (11th ed.). Jakarta: PT Raja Grafindo Persada.

Jennings, P. a, \& Greenberg, M. T. (2009). The Prosocial Classroom: Teacher Social and Emotional Competence in Relation to Student and Classroom Outcomes. Source: Review of Educational Research, 79(1), 491-525. http://doi.org/10.3102/0034654308325693

Joy, Hamilton, T., \& Ekeke. (2013). Conceptual Framework Of Teachers' Competence In Relation To Students' Academic Achievement. International Journal of Networks and Systems, 2(3), 6.

Kunter, M., Klusmann, U., Baumert, J., Richter, D., Voss, T., \& Hachfeld, A. (2013). Professional Competence of Teachers: Effects on Instructional Quality and Student Development. Journal of Educational Psychology, 105(3), 805-820. http://doi.org/10.1037/a0032583

Lee, J., Liu, X., Amo, L. C., \& Wang, W. L. (2013). Multilevel Linkages Between State Standards, Teacher Standards, and Student Achievement: Testing External Versus Internal Standards-Based Education Models. Educational Policy, 28(6), 780-811. http://doi.org/10.1177/0895904813475708

Levpuscek, M. P., \& Zupancic, M. (2008). Math Achievement in Early. Journal of Early Adolescence, $X X(\mathrm{X}), 1-30$. http://doi.org/10.1177/0272431608324189

Linnenbrink, E.A., Pintrich, P. R. (2002). Motivation as an Enable for Academic Success. School Psychology Review, 31(3), 313 - 327.

McInerney, D. M., Cheng, R. W.-Y., Mok, M. M. C., \& Lam, a K. H. (2012). Academic self-concept and learning strategies: Direction of effect on student academic achievement. Journal of Advanced Academics, 23(3), 249-269. http://doi.org/10.1177/1932202X12451020

Mudjiono, D. (2009). Belajar dan Pebelajaran. Jakarta: Rineka Cipta.

Muzenda, A. (2013). Lecturer s ' Competences and Students' Academic Performance. International Journal of Humanities and Social Science, 3(1), 6-13.

Nemeth, J., \& Long, J. G. (2012). Assessing Learning Outcomes in U.S. Planning Studio Courses. Journal of Planning Education and Research, 32(4), 476-490. http://doi.org/10.1177/0739456X12453740

Omar, S., Jain, J., \& Noordin, F. (2013). Motivation in Learning and Happiness among the Low Science Achievers of a Polytechnic Institution: An Exploratory Study. Procedia - Social and Behavioral Sciences, 90(InCULT 2012), 702-711. http://doi.org/10.1016/j.sbspro.2013.07.143

Ottmar, E. R., Rimm-Kaufman, S. E., Larsen, R. a., \& Berry, R. Q. (2015). Mathematical Knowledge for Teaching, Standards-Based Mathematics Teaching Practices, and Student Achievement in the Context of the Responsive Classroom Approach. American Educational Research Journal, 52(4), 787-821. http://doi.org/10.3102/0002831215579484

Porter, T. S., Riley, T. M., \& Ruffer, R. L. (2004). A Review of the Use of Simulations in Teaching Economics. Social Science Computer Review, 22(4), 426-443. http://doi.org/10.1177/0894439304268464

Shatzer, R. H., Caldarella, P., Hallam, P. R., \& Brown, B. L. (2013). Comparing the effects of instructional and transformational leadership on student achievement: Implications for practice. Educational Management Administration \& Leadership, 42(4), 445-459. http://doi.org/10.1177/1741143213502192

Siska Eko Mawarsih, D. (2013). Pengaruh Perhatian Orang Tua dan Motivasi Belajar terhadap Presatsi Belajar Siswa SMA Negeri Jumapolo. JUPE UNS, 1(3), 1-13.

Sugiyono. (2015). Metode Penelitian Pendidikan (Pendekatan Kuantitatif, Kualitatif dan R\&D). Bandung: Alfabeta.

Swanson, J., Valiente, C., Lemery-Chalfant, K., \& Caitlin O'Brien, T. (2011). Predicting Early Adolescents' Academic Achievement, Social Competence, and Physical Health From Parenting, Ego Resilience, and Engagement Coping. The Journal of Early Adolescence, 31(4), 548-576. http://doi.org/10.1177/0272431610366249

Syaiful, S. (2012). Kemampuan Professional Guru Dan Tenaga Kependidikan. Bandung: Alfabeta.

Tirtarahardja, U dan La Sulo, S. L. (2012). Pengantar Pendidikan. Jakarta: Rineka Cipta.

Uma, S. (2006). Metodologi Penelitian untuk Bisnis (4th ed.). Jakarta: Salemba Empat.

Wayne, A. J., \& Youngs, P. (2003). Teacher characteristics and student achievement gains: A review. Review of Educational Research, 73(1), 89-122. http://doi.org/10.3102/00346543073001089. 